\title{
SOBRE UMA CARTA DE HENRY MILLER
}

\section{Helena Martins e Marcia Sá Cavalcante Schuback}

\section{À guisa de apresentação}

Entre os anos de 1930 e 1938, Henry Miller reside praticamente todo o tempo em Paris. Esse período é marcado pela forte influência exercida pelo amigo e escritor Michael Fraenkel, a quem é apresentado logo nos primeiros tempos dessa temporada francesa, quando, conta-nos, "não tinha um tostão, comia de favor e dormia em

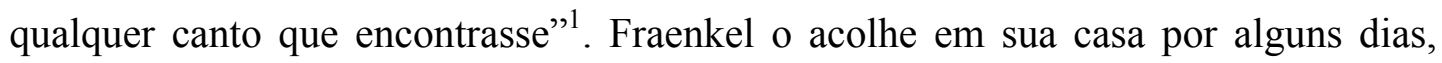
começo de uma longa e vigorosa convivência.

Em 1934, no dia do lançamento de Trópico de Câncer na França, Miller se muda para o edifício de Fraenkel, na Villa Seurat, endereço que logo se torna ponto de grande efervescência artística e cultural. Quando Fraenkel publica em 1935 o livro Bastard Death. Autobiography of an Idea [Morte bastarda. Autobiografia de uma idéia], é Miller quem escreve o prefácio.

Sobre esses tempos, Miller nos diz:

Era comum que [Fraenkel] chegasse para o café-da-manhã, ficasse para almoçar e para jantar, e só por volta da meia-noite voltasse aos seus domínios. Dia e noite só fazíamos conversar, conversar, conversar. Acho que ele teria preferido chamar de discussões aquelas conversas. Para mim eram tudo menos discussões. Não pareciam levar a parte alguma, mas me fascinavam, e eu terminava os dias exausto. É difícil imaginar duas pessoas mais diferentes do que Fraenkel e eu. Ele tinha um espírito, por assim dizer, "rabínico", afiado como lâmina de navalha. Nunca perdia o fio. Acho que eu também falava bastante. Mas nunca tinha conhecido alguém como Fraenkel. Conversar para ele era como respirar. Era simplesmente impossível que dissesse uma frase comum, uma afirmação. Tudo o que dizia me soava provocador. ${ }^{2}$

\footnotetext{
${ }^{1}$ Henry Miller, em prefácio à edição americana (Hamlet Letters, Capra Press, 1988).

2 Idem.
} 
Certo dia, no café Zeyer, depois de alguns meses nessa rotina, Fraenkel sugere a Miller que passem a trocar cartas, em vez de conversar. Miller rememora a ocasião:

- Sobre que tema? - perguntei.

- Ah, sobre tudo e qualquer coisa - acho que foi assim que me respondeu.

- E que título daríamos às cartas?

Ele sorriu aquele sorriso sardônico que lhe vinha tão fácil e pôs-se a enumerar títulos possíveis. Eram todos bem ruins - ele não parecia se importar tanto com a escolha do título. Preocupava-se mais em garantir que o livro tivesse exatas 1.000 páginas.

— Na milésima página — acrescentou — nós paramos, mesmo que seja no meio de uma frase.

Antes de sair do café naquela tarde, tínhamos concordado que o título do livro deveria ser "Hamlet" (quase nos decidíramos por "A viúva alegre").

As cartas que os dois trocaram entre 1935 e 1938 não chegaram afinal às mil páginas, interrompidas mais ou menos a meio caminho em outubro de 1938, véspera da guerra: "[s]entado à beira de um vulcão para encerrar o nosso dueto", escreve Miller em sua última carta, "trabalho de malas prontas e chapéu na cabeça — ao primeiro toque da sirene, sumo daqui" ${ }^{3}$.

Ainda que não na cifra prevista, as cartas foram publicadas com o título combinado, pela editora Carrefour, de Nova York, em dois volumes. Como forma de escapar aos então vigilantes censores americanos, o primeiro volume saiu em Porto Rico, em 1939; e o segundo, no México, em 1941. Uma tradução para o francês foi lançada em 1956, pelas Éditions Corrêa, Buchet/Chastel, em Paris, segundo Miller com alguns cortes. Depois da morte de Fraenkel, em 1957, sua viúva, Daphne Moschos, herdeira dos direitos do livro, publicou uma edição na Inglaterra, pela qual Miller, por mais insatisfeito que se tenha demonstrado, nada recebeu. Mais tarde, ela vendeu os direitos a um fã americano de Miller, Michael Hargraves, responsável por uma edição de 1988 (Capra Press), na qual, por pressão comercial, excluíram-se as cartas de Fraenkel.

A versão completa da correspondência (1939-1941) está esgotada: aos interessados resta hoje visitar algumas poucas bibliotecas que dispõem dos dois

\footnotetext{
${ }^{3}$ Miller, Henry e Fraenkel, Michael. Hamlet. New York: Carrefour, 1939, p. 366-367.
} 
volumes, ou enfrentar acirradas disputas no mercado de livros usados. É estranho que uma obra tão relevante arraste uma história editorial tão conturbada.

Mais do que um estudo sobre o Hamlet de Shakespeare, o livro nascido da correspondência dos dois escritores apresenta uma profunda discussão sobre a distinção, tão decisiva para Henry Miller, entre intelecto (território das abstrações racionais) e inteligência. Fraenkel parece enredado na trama das idéias enquanto Miller fala em nome da poesia, da intuição intelectual e da verdade. Não há dúvida de que Miller admirava Fraenkel, que era para ele um "possuído". Fraenkel é o modelo para o Boris de Trópico de Câncer: preso na malha das ideias e, à semelhança de Hamlet, incapaz de agir.

O drama de Hamlet, o drama do homem moderno, o drama da consciência é tratado nessa correspondência como o próprio drama da escritura, da relação entre idéia e experiência, formalismo e vitalidade criadora, entre Fraenkel e Miller.

Respondendo ao tema deste número de Tradução em revista, as autoras publicam aqui uma tradução da carta que abre essa rica troca epistolar, escrita por Henry Miller no dia 2 de novembro de 1935. Sob o impacto do que ali se oferece ao pensamento, desejaram também escrever sobre a carta. Vivendo uma no Rio de Janeiro e a outra em Estocolmo, julgaram que estaria no tom deste volume trocarem cartas, conversarem por escrito. 


\section{De Henry Miller para Michael Fraenkel ${ }^{4}$}

Caro Fraenkel,

2 de novembro de 1935.

Ontem à noite fui para os lados da Escola Militar. Era dia de Todos os Santos. Eu estava voltando de um passeio na Rua Saint Dominique, passeio que fiz deliberadamente porque buscava recordar certas emoções. Senti exatamente o que eu queria redescobrir e, sentando-me ao ar livre em um café, pus-me a ruminar minhas emoções. Comecei a pensar em Hamlet. Disse a mim mesmo que era preciso estar com a cabeça torta para pensar em Hamlet num dia assim, dia de Finados na França, quando os espécimes mais hediondos da flora burguesa se apossam da rua. Nenhum francês no mundo teria podido compreender o caos do meu espírito. Eu os via passar ao redor, com suas vestes negras, e não havia um só que pensasse remotamente em Hamlet ou em qualquer outra coisa do universo anglo-saxão de onde Hamlet brotou. Se Hamlet é, eu ia pensando, a imagem perfeita da morte-em-vida, então o que seriam eles, esses fantasmas que passavam me esbarrando? A vida e a vida bastarda, diz você no seu livro. Só que nesse caso Hamlet é a vida; e essa, nada mais que uma vida bastarda. E no entanto todas essas pessoas fazem alguma coisa; todos têm uma meta, um desejo, uma direção. Não é que o façam da mesma maneira que os alemães ou os americanos. Isto aqui é vida francesa: nada mais perfeitamente coerente e vazio. Como então falar aqui sobre Hamlet? Por que Hamlet? Hamlet é o drama da alma nórdica, um drama que se passa inteiramente fora dos limites dessa realidade que os franceses chamam de vida.

Não é estranho que estejamos os três aqui na França, e que nenhum de nós seja francês? ${ }^{5}$ E Fred, que adotou a França, que pensa e escreve em francês, Fred é, de nós três, o menos francês. Um belo dia, no café Zeyer, decidimos escrever este livro. Não é um livro que possa agradar aos franceses. Tampouco é feito para os nossos compatriotas americanos. É, não obstante, um livro nascido da França e da

\footnotetext{
4 Tomamos por base a primeira edição, de 1939.

5 Além de, Fraenkel, que nasceu na Lituânia e emigrou para os Estados Unidos com a família aos oito anos, Miller se refere aqui a um amigo comum, Fred, apelido do escritor austríaco Alfred Pérles.
} 
América. Nascido num momento de grande lassidão, nascido do desespero causado pela inércia e pela paralisia que nos cercam.

Assim, no terraço de um café, perto da Escola Militar, tento lembrar a estória de Hamlet, tal como Shakespeare a contou para nós. Era uma vez um jovem dinamarquês doentio, gênero poeta, incapaz de agir. Sua famosa tirada sobre o suicídio - "ser ou não ser" — parece ter causado grande impressão sobre o mundo. Ele morre no final e com ele um certo número de pessoas. Deixa para nós as suas dúvidas, as suas ruminações. Segundo opinião quase unânime, é uma das melhores peças escritas por Shakespeare.

Eis aí a peça. O efeito porém é outra coisa - coisa bem desproporcional à peça; mesmo se esta fosse a maior peça de todos os tempos, o que não é o caso. Por que então Hamlet, tão solidamente enraizado em nossa consciência, que só desaparecerá quando tiver sido varrida do mundo toda a civilização ocidental?

Parece-me que a resposta se encontra no entusiasmo com o qual nos decidimos realizar esta obra. Hamlet está em nossas entranhas. É essa abulia, esse caos, esse desejo de um para além que nos distingue dos franceses. É isso que murmura eternamente em nossas veias, e que faz com que sejamos batidos pela vida. Muitos Hamlets antecederam Shakespeare. Com Shakespeare é, contudo, o verdadeiro Hamlet que se realiza. Ele surge no ápice do Renascimento. Ele jorra do terceiro olho.

Ontem à noite, antes de me deitar, folheava um livro de Denis Saurat chamado Modernes, quando me deparei com a seguinte passagem:

"Proust é o escritor de gênio que até hoje melhor exprimiu certo aspecto do homem, esse aspecto que chamamos de moderno. Ele não exprimiu, porém, o homem todo, mesmo do ponto de vista moderno. Ou seja, ainda há lugar no estilo moderno para um gênio de primeira ordem, que partiria do moderno, como Hugo partiu do romântico, e atravessaria o homem todo, assim como fez Hugo, ou Shakespeare ou Cervantes. Isso foi o que Proust não fez".

E então ele acrescenta o seguinte: "Seria preciso um escritor que, sendo naturalmente moderno, pudesse esquecer que é moderno e nos apresentar o quadro 
do mundo sem precisar insistir sobre esse aspecto, já que lhe seria natural ver assim o mundo". 6

O que na passagem acima me parece tolo, mas também significativo, estimulante, provocador é o pequeno parêntese: "sendo naturalmente moderno". Esperar uma atitude natural do moderno, que é por essência um ser desnatural, é para mim o auge do pensamento equivocado francês. Paradoxalmente, a França é o único lugar em que essa atitude natural diante do desnatural veio a manifestar-se, para logo sucumbir, é claro, sob os poderosos holofotes do drama hollywodiano de Apolo, que os franceses não cessam de encenar há mais de um século. Ser naturalmente moderno é ser um monstro natural, um Hamlet elevado à enésima potência. Quando esse monstro fizer sua aparição, o mundo moderno se sentirá tão livre que haverá de estourar os miolos...

Falando sobre o Édipo de Sófocles, Nietzsche tenta nos explicar que o sentido da peça estava em mostrar que "o homem nobre não peca". "Por sua ação", Nietzsche acrescenta, "pode desaparecer toda e qualquer lei, toda ordem natural, e mesmo o mundo moral"; mas é "precisamente por este modo de agir que se traçará um circulo mágico, mais elevado de influências, influências estas que edificarão um mundo novo sobre as ruínas do velho e tombado"?. Eis em poucas palavras o que separa o mundo antigo, em seu apogeu, do mundo moderno de Hamlet. O homem nobre não peca, diz Nietzsche. Será preciso aguardar Rimbaud para escutarmos um eco fraco de tudo isso. Digo fraco porque, em Rimbaud, o sentimento de culpa se atrofia mas não consegue ser dominado. E aí vemos novamente o abismo que separa o mundo moderno do antigo mundo grego. Édipo é o supremo drama da culpa. Estabelece para sempre a inocência divina do homem. Já Hamlet, o supremo drama da dúvida, carrega o peso do crime de dois mil anos de sofrimentos insuportáveis, símbolo mesmo da falência interior do homem moderno.

Mas retornemos às circunstâncias que cercaram a concepção do nosso livro, do nosso Hamlet. (As condições não se modificaram desde então). De início,

\footnotetext{
${ }^{6}$ Optamos por traduzir as passagens de Saurat, citadas por Miller em francês no original.

${ }^{7}$ A tradução em português da passagem de Nietzsche aqui utilizada é de Erwin Theodor. A Origem da Tragédia Proveniente do Espírito da Música, Editora Cupolo, 1948.
} 
pensamos em pegar um livro mal escrito de um autor famoso qualquer e reescrevêlo à nossa maneira. Seria importante, no entanto, que todo mundo pudesse reconhecer a história, só lendo o título. Depois de quebrarmos a cabeça durante alguns dias, chegamos à conclusão de que isso não valia a pena, acreditando que poderíamos descobrir nós mesmos um assunto para desenvolver. Vimo-nos então inevitavelmente diante da alternativa entre os títulos A Viúva Alegre e Hamlet. Veja bem, como é moderno pensar que não há diferença entre Hamlet e a Viúva Alegre! E, repare, não é só isso... não é verdade que decidimos escrever mil páginas, nenhuma a mais e nenhuma a menos? E Hamlet? As mil páginas adquiriram mais importância do que o próprio Hamlet. Hamlet, a bem dizer, não tem começo nem fim. O mundo inteiro tornou-se Hamlet e nada do que possamos dizer será capaz de adicionar ou subtrair qualquer coisa ao tema.

Isto é Hamlet! E nossa empreitada só terá êxito no dia em que tivermos espantado o fantasma. Pois Hamlet ainda anda à espreita pelas ruas. A culpa não é de Shakespeare. É nossa. Nenhum de nós é ainda suficientemente moderno para ludibriar esse fantasma e torcer-lhe o pescoço. O fantasma não é o pai assassinado nem a consciência atormentada; é a alma do tempo, que range como um pêndulo enferrujado. Nossa tarefa neste livro é acertar o balanço do pêndulo, para estarmos novamente em harmonia com o passado e o futuro. Está em desordem o tempo? Olhem o relógio! Não o relógio sobre a lareira mas aquele cronômetro interior que indica quando estamos vivendo e quando não estamos. Ou ainda, devo dizer à meia voz: livrem-se de todos os relógios de hoje em dia! Não queremos saber a hora pelo sol ou pela lua, mas pelo passado e pelo futuro. Estamos hoje com o tempo até o nariz: tempo da rádio Western Union, tempo padrão [Eastern Standard], tempo de Greenwich, tempo sideral, tempo einsteiniano, tempo de ler um pouco, tempo de ir dormir, todos os tipos de tempo que não nos dizem o que se passa dentro de nós, e nem mesmo em torno de nós. Movemo-nos na escada rolante do tempo...

Foi no dia em que decidimos escrever este livro, foi nesse dia que fizemos a experiência do tempo real. Nesse dia, o universo inteiro tornou-se nossa propriedade privada. E meu mindinho me diz que amanhã de manhã, ao despertar, você terá 
decidido revolucionar os seus hábitos monacais e se jogará nas ruas. O que aconteceu com você eu prefiro me abster de perguntar por agora. Mas você caiu nos canos, nos buracos, nos esgotos abertos da vida. Você até tomou um café-da-manhã reforçado antes de sair, outra violação a sua regra de vida. Pôs-se a caminho, um peso assassino nos olhos, em busca de Hamlet. Você abandonou seu próprio Hamlet para espantar o fantasma. Eu espero, meu caro Fraenkel, que você continue caminhando. Você ainda tem uma boa estrada pela frente, mil páginas, antes de cumprir a sua tarefa. E eu sei, mesmo antes de chegarmos à milionésima página, que você não ressuscitará o espectro. Sei que no final nos veremos no seu apartamento, e você nos contará sobre a "face noturna" e a "face diurna" do mundo. Mas você iniciou algo e assim entrou no mundo. Outros seguirão, talvez. Isso talvez provoque uma migração, uma grande debandada em direção ao mundo antimoderno do tempo real.

No momento de concluir esta primeira carta, observo que o calendário indica 7 de novembro! Como confiar nesse calendário falso, já que, segundo a minha cronologia, são sempre ainda 2 de novembro, e eu não me mexi do terraço do café perto da Escola Militar? Mas talvez seja bom assim, que tudo o que tenho para dizer eu haverei de escrever desse terraço tão agradável e repousante para o espírito. Faz um calor excepcional para um mês de novembro. Pedi ao garçom um pouco de sorvete no meu Byrrh-Cassis.

Antes de continuar, quero fazer algumas perguntas, pois faz uns 18 ou 20 anos que não releio Hamlet. 1) Hamlet se mata no final? E se não, por quê?; 2) quem são os mensageiros misteriosos, Rosenkrantz e Guildenstern?; 3) São judeus ou dinamarqueses? Qual o objetivo da viagem deles?; 4) Ofélia, do que eu me lembro, sempre me pareceu um pouco simplória. Gostaria de saber se é uma falsa impressão ou uma astúcia de Shakespeare; 4) A ação se passa na Inglaterra ou na Dinamarca? Se nesta última, por que tenho a sensação de que é na Inglaterra?; 5) A morte de Polônio é acidental ou um homicídio premeditado? E qual a relação entre Laércio e Polônio, se é que há uma? 6) Devo ler a peça para ver como é ou será melhor ficar com a minha primeira impressão de Hamlet?

Henry Miller 


\section{De Helena Martins para Marcia Sá Cavalcante Schuback}

Querida Marcia,

O carnaval aqui chega cada vez mais cedo e é ao som meio inverossímil de Índio quer apito, sem ar-condicionado e num calorão de quarenta graus que eu começo a escrever esta carta. Por estranho que pareça, nada disso me chateia muito, nem me afasta do lugar pra onde eu fui literalmente tragada ao ler e traduzir com você essa primeira, incrível, carta da Correspondência Hamlet. Na verdade, o estranhamento entre o batuque vindo da janela e os assuntos altíssimos que eu entrevejo naquelas linhas me faz lembrar o descompasso que o próprio Miller (anglosaxão pensando em Hamlet no meio dos franceses) descreve logo na abertura da sua carta.

Mas eu devo dizer que não é bem a figura mais imediata da distância, do lapso entre o que vai no espírito e o que vai no mundo, não é isso o que me leva a traçar esse talvez presunçoso paralelo de circunstâncias.

Acho até que é bem o contrário: uma das coisas de que eu mais gosto na carta, em Miller, é essa intromissão contínua do mundo, essa espécie de fustigar insistente da vida - bastarda ou não. O café, a rua, pessoas esbarrando, o dia de Finados, o ar. É um pensamento que parece preferir levar aonde vai a cadeira, o copo, o terraço e todo o seu dispersivo (não raro repulsivo) entorno. Adoro isso. Fico então entre surpresa e agradecida ao reconhecer que o lugar pra onde sou tragada lendo a carta tão estrangeira de Miller a Fraenkel é, de um modo meio paradoxal, aqui mesmo: inclui o barulho do surdo, o calor, essa luz irrecusável de horário de verão, a alegria semifalsa do pessoal cantando lá fora.

Mas será que daqui eu consigo apitar alguma coisa?

Começo, com rede de segurança, por um detalhe que achei curioso: reparou que já no iniciozinho da carta começa a se insinuar a irreverência cronológica que Miller tornará mais explícita no final, quando põe em marcha o seu inflamado ataque contra os desmandos do calendário institucional? Veja que a carta é datada de 2 de 
novembro, dia de Finados. E que começa narrando o que se passara no dia anterior, 1 de novembro, dia de Todos os Santos. Mas antes do parágrafo terminar, o dia de Todos os Santos já virou dia de Finados; o ontem já virou hoje; todos os santos, todos os mortos.

Bom, o tempo. Concorda que The time is out of joint é uma espécie de divisa da carta? Dificílimo traduzir isso, não? Quando Miller transforma o famoso veredicto de Hamlet em pergunta retórica (alterando-o ligeiramente) - Are the times out of joint? —, nós optamos por traduzir assim: “está em desordem o tempo?”. Nas edições de Hamlet em português, encontro outras possibilidades: "dos gonzos saiu o tempo" (Ridendo Castigat Mores), "o tempo está fora dos eixos" (Millôr Fernandes ), "o tempo é de terror" (Barbara Heliodora), "desconjuntou-se o tempo" (Sophia de Mello Breyner). Ênfases distintas, colaboráveis: a bagunça de uma era; o drama de um súbito desconcerto; a imobilidade aterradora do mecanismo quebrado; o tempo desnorteado, fora dos eixos norte-sul, leste-oeste. Mas sobretudo, pelo que pude entender, as juntas deslocadas no corpo do tempo: passado, presente e futuro desconjuntados.

Miller diz, sem extravagância, que o homem moderno é este que está em desarmonia com o passado e o futuro. O homem moderno. Me ocorre que a carta foi escrita há quase oitenta anos. Lembro que quando falei sobre ela em um congresso na Escócia senti, sei lá por quê, a necessidade de reconhecer o óbvio: que, ditas por bocas dos anos 1930, palavras como "moderno" haveriam de exercer outros impactos, projetar outros futuros, hoje talvez (pós-modernamente) indiscerníveis. Enquanto eu ia falando isso, um professor americano, figurão cujo nome agora me escapa, balançava uma aprovativa cabeça, balanço este interrompido com um tsk-tsk, tão logo eu acrescentei que não achava de modo algum extemporâneos os imperativos, os apelos, as urgências de Miller, seu tom quase militante, seu interesse numa "migração para o mundo antimoderno do tempo real". Tsk, Tsk: tempo real?! Não dá mais pra falar disso hoje em dia não — foi o que eu li naquele olhar de “perdoai-os, Pai, eles não sabem o que fazem” que o tal professor me lançou. Tentei, 
mas acho que não consegui, dar o troco na mesma moeda, respondendo com um olhar de "Ué: lá onde você mora ainda tem esse negócio de contramão da história?!"

Brincadeiras à parte, me interessa muito na carta de Miller que o diagnóstico sombrio dos tempos não venha com indiferença, cinismo ou conformismo. Gosto do que há ali de exortativo, gosto até do que acho um pouco exagerado. Pouco me importa se os tempos eram outros: eu escuto o que diz a carta e quero entender, reconheço-me como destinatária, reclamo o que ali promete catalisar.

Achei, por exemplo, notável a passagem em que Miller se espanta com a expressão "naturalmente moderno", usada pelo escritor Denis Saurat. O espanto a princípio se justifica se com Miller lembramos que a característica principal do moderno é não ser natural, ser desnatural. Nem por isso, no entanto, as palavras de Saurat se deixam descartar com ligeireza, acolhem pacíficas o atributo de "pensamento frânces equivocado". A impressão que me deu é que Miller toma a expressão "naturalmente moderno" de um jeito meio oximorônico: seria algo a um só tempo tolo e significativo, ameaçador e auspicioso, interditado e esperado.

Mas queria saber o que você acha: o que poderia significar ser naturalmente moderno? Ser esse "monstro natural", esse "Hamlet elevado à enésima potência"? Um perigo? Um caminho de volta? De ida? Uma possibilidade real? Qual é a relevância disso para nós hoje? Acho tudo isso dificílimo.

Claro que enquanto Saurat parece ter em vista a realização plena de um determinado estilo literário, Miller fala em termos mais amplos e bastante conhecidos: toma o moderno como condição ou configuração - como uma certa forma de estar no mundo, ou talvez como um certo mundo. E é Hamlet que ele elege como arquissímbolo para essa condição. Algo talvez próximo de um caráter viqueano? Hamlet estando para a idade dos homens como Homero estaria para a idade dos heróis? Qualquer que seja o caso, Miller nos diz, Hamlet "está em nossas entranhas".

E o que em Hamlet marcaria particularmente o espírito do tempo? Miller é incisivo: "Hamlet é o supremo drama da dúvida". A dúvida que detém o ato, o gesto espontâneo, que assombra e paralisa, que move a busca incessante da prova, de um 
por trás, de um fundo. A dúvida que nos põe talvez em guarda contra o mundo, que impede a palavra de atravessar a barreira dos dentes, por medo de que traia o engano. Dúvida do passado, dúvida do futuro: dúvida do presente (também no sentido de dom). Não só a dúvida intelectual, aquela mais ou menos pacificável com os "panos quentes" de um filosofema: ceticismo. Mas também essa espécie de esvaziamento do espírito, que faz desconfiar e até mesmo abrir mão do mundo. O motivo da perda da fé - a súbita incapacidade de ter fé no absurdo, justamente porque é absurdo, diria, se eu me lembro bem, Kierkegaard. Acha bobagem?

Hamlet "está em nossas entranhas", "murmura eternamente em nosso sangue", toma o lugar de Deus: "não tem começo nem fim". Mas ao mesmo tempo Hamlet é o Ocidente moderno, é o que deixa para trás as promessas remotas da Grécia arcaica, o que dá as costas para, sei lá, o louco, o índio, o velhinho chinês, a criança, todos os nossos "outros" de plantão.

Mas então Hamlet é nossa natureza eterna e é também nossa circunstância cultural? Como é que fica isso?

E que perigos, que portas se escondem nessa história elevar Hamlet à enésima potência? Como é isso de espantar um fantasma fortalecendo-o ao máximo? Não creio que Miller esteja se referindo ao tipo de coisa que fez Descartes, por exemplo, com a sua dúvida hiperbólica. Nem me parece que ele tenha sido um soldado nas cada vez mais numerosas fileiras de mortos-vivos dispostos aceitar com paralisia, indiferença e cinismo a inexpressividade e o sem-sentido de tudo: já disse, muito ao contrário.

Não sei se entendo muito bem, mas parece haver alguma coisa nessa imagem engraçada (irônica) de Hamlet jorrando do terceiro olho. O terceiro olho nomeia, fiquei besta de saber, a glândula pineal, o tal lugar que comunicaria as substâncias estranhas do corpo e do espírito (de novo, Descartes...). Mas é também o símbolo da intuição aguda, da percepção especial. Que desse estado perceptivo jorre Hamlet, o supremo drama da dúvida!

Não se exclui daí a possibilidade - e acho que é um pouco por conta dela que o próprio Shakespeare me arrebata - de que ser naturalmente Hamlet, 
naturalmente moderno, envolva o discernimento de que podemos nos tornar algo distinto do que somos, ou talvez de que já somos algo bem distinto do que somos: monstros. Encarar o horror do monstro, reconhecendo nele não a aberração da natureza, mas $a$ (nossa) natureza: o monstro natural, subtraído da terra das exceções, sua perigosa mas vital e promissora liberdade.

Para isso é necessário, acho, a hoje dificílima tarefa de, digamos com Spengler (acho), entrever a natureza viva de Goethe na natureza morta de Newton. Natureza mergulhada no tempo real, em que a substância não é mais o parâmetro último - natureza feita não tanto de coisas, mas de atos, de movimento e de linguagem. Sem que, no entanto, isso dê sempre ensejo à decepção, à nostalgia ou à desconfiança. Espanto apenas, talvez: de que há linguagem, há línguas, são diferentes, são mundos.

Bom, tenho que terminar, e vai ser abrupto, ficando por dizer, como sempre, quase tudo o que importa.

Me parece que de alguma forma Miller nos convida a aceitar o inexplicável pelo que é: inexplicável. Aceitar não sendo aqui conformar-se com o inexplicável, mas antes, talvez, acolhê-lo, dispor-se a habitar as suas infinitas e arriscadas possibilidades; dispor-se, como nós nos dispusemos, a traduzir.

Forcei? Hesito, por vergonha, a deixar essa última parte (a carta inteira?). Mas ando me esforçando para adotar o novo lema do meu irmão: só o constrangimento salva.

Em todo caso, me tira do mau caminho se achar que é o caso?

Abração grande e saudoso!

Helena 


\section{De Marcia Sá Cavalcante Schuback para Helena Martins}

Querida Helena,

A sua carta chegou como um raio de luz na noite das correrias. A própria dificuldade de encontrar uma brecha de tempo para finalizar a tradução da primeira carta de Miller a Fraenkel e responder a sua carta e conseguir fazer isso "a tempo" dá a batida do tempo out of joint que é, como você tão claramente apontou, a divisa da carta. Tempo desconjuntado, tempo fora das juntas da vida, não será Hamlet, o drama do tempo fora do tempo, o drama do tempo extemporâneo? Penso nas condições de temperatura e pressão sob as quais estamos escrevendo as nossas cartas sobre as cartas e na distância que nos separa e nos separa também das Cartas, do Hamlet. Você falou do calor pré-carnavalesco e eu li essas palavras sob uma temperatura sueca de menos 16; aí o batuque de tantas precipitações, aqui a mudez de tantas introversões (o inverno é a introversão da terra, disse Rilke num poema); aí a vida extrapolada; aqui a vida desapontada; sul e norte, quente e frio, verão e inverno; o tempo como estação, o tempo que se diz não como relógio e horas mas como "clima" - que tempo está fazendo?, o clima do moderno, o clima como um temperamento, um sentido de tempo fora do sentido cronológico do tempo, mostrando o tempo como a batida e a medida do homem no todo do mundo.

Ainda refletindo sobre as circunstâncias da nossa correspondência, ontem à noite vi na televisão a versão do Hamlet, pura coincidência, com David Tennant e Patrick Stewart, mostrando um Hamlet atualizado, um Hamlet onde o tempo da peça era só temperamento e que, não obstante uma tendência para a histeria performática, deixou o texto falar, de novo, o mesmo, de maneira nova, a ponto de me perguntar por vezes se não era a primeira vez que lia esse texto. E ontem mesmo, ligando para um grande amigo sueco que vive perto de Helsinborg para desejar feliz aniversário, o meu celular o encontra no barco passando em frente ao castelo de Amlet, em Helsingör, na hora exata em que eu telefonei. Tudo isso me lembrou que estou aqui 
na paisagem da frieza, no nórdico de Hamlet, estou aqui sem ser daqui e, portanto, sempre trazendo o longe daqui, que é o aí, onde você está, você que está na minha saudade e, portanto, no longe que é o mais perto possível. Tempo como clima, tempo como coincidência, tempo sem tempo, enfim, foi nesses tempos que recebi sua carta, que reli nossa tradução das Cartas e que me pus na luta para conseguir um tempo para responder a carta a tempo para a edição da revista.

Não sei se seria precipitar demais ou projetar demais sobre as Cartas dizer que esse tempo desconjuntado, out of joint, esse desconjuntamento de passado, presente e futuro que define o moderno é precisamente o que explica como o moderno como a "nossa natureza eterna" é também "uma circunstância cultural", como Hamlet é a nossa entranha. Falar hoje de moderno parece bem fora do tempo. A condição pós-moderna (Lyotard) ou alteromoderna (Negri/Hardt) pretende descrever uma condição em que a dramaticidade de um passado assassinado (o rei, o pai) e de um deus morto, o desespero e a dúvida que aparecem quando tudo perde sentido e a falta de sentido se espalha como um novo céu sobre todos os confins da existência perdem sua dramaticidade, tornam-se normalidade. Essas expressões pós-modernidade ou alteromodernidade — continuam, porém, a nomear o moderno. Elas confirmam um sentido do moderno que me parece central nessa primeira carta de Miller, o sentido de um fim que não consegue acabar, um eterno fim, ou seja, um não-começo, um sempre ainda-não.

Esse é o drama de Hamlet e por isso não é de estranhar que Miller não se lembre se Hamlet se mata ou não no final, pois Hamlet não morre mesmo quando morto. O fim que é Hamlet — death-in-life, "morte-na-vida" não morre. E a questão é como um fim que não acaba de acabar é ou pode ser começo.

A pergunta mais decisiva é, como você colocou, aquela sobre a natureza desnatural. Fiquei em dúvida sobre como traduzir unnatural, unanturalness, pois fiz uma associação entre a natura naturans em Spinoza e Schelling e a unnatural nature de Hamlet; e uma expressão inusitada me apareceu - natureza desnaturada. Não seria uma solução de tradução mas o modo como estou tentando entender Miller aqui. Acho que é o mesmo problema do começo numa experiência de fim que não 
acaba de acabar. Você colocou tão bem essa questão ao falar da necessidade "moderna" de descobrir a natureza viva de Goethe na natureza morta de Newton. Lembrei-me do primeiro pintor negro brasileiro a se formar na Academia Real de Belas-Artes, Estevão Silva (1845-1891), que chegou a cortar algumas de suas telas de natureza-morta e enxertar ali frutas naturais, o odor da natureza viva nas cores da natureza-morta. A pergunta se repete, exponenciando-se, em como a desnaturação da natureza ainda é natureza, como morte-na-vida pode ainda ser vida?

Miller lê o livro de Saurat e descobre o limite de Proust: apresentar-se como um observador do moderno, um espectador de Hamlet, alguém que ainda consegue diferenciar-se, ou bem por indignação ou por indiferença ao moderno. Só que o problema não está em encontrar uma negação da negação - negar o moderno tomado como negação do antigo ou da natureza - mas em descobrir um outro tipo de sim, que não é reativo, vingativo ou fugitivo. Um fim que não acaba de acabar não dá espaço para negações, aparecendo como um sem-saída e sem-entrada, um se correr o bicho pega, se ficar o bicho come. Mas quando o sentido de negação se rompe ou suspende e o sem sentido se torna o céu do homem parece que uma decisão mais enfática tem lugar e se torna um tempo. Essa decisão mais enfática seria o que você descreveu tão bonito de acolher o monstro não como aberração mas como promessa de liberdade. Algo como descobrir no sem-saída e no sem-entrada possível a gratuidade da "vida bastarda", [título inspirador do romance de Fraenkel, que ainda hoje não consegui encontrar em parte alguma para ler. Confesso que me pergunto se ele de fato existe!]. Pois sob o céu do sem-sentido ou bem se sucumbe em inúmeras formas de niilismo, ativo e passivo, suicídio ou morto-vivo, ou bem se descobre que vida é radicalmente bastarda, "herança sem testamento" (René Char), "jagunço" (na sublime etimologia de ser jogado que sustenta a poética de Guimarães Rosa). A dúvida de Hamlet é o desespero de encontrar um porquê assegurador de sentido, o desespero de não suportar orientar-se pelo o céu do sem-sentido e suas estrelas sem luz, sua luz sem estrelas mas sempre ainda luz-estrela. Hamlet aparece como louco, fantasma, morto-vivo, mostrando o desespero de palavras sem 
pensamentos, de pensamentos sem palavras e de como um pensamento incapaz de esquecer só pode levar à loucura.

Mas o que Hamlet mostra é como esse fim que não acaba de acabar é ele mesmo começo. Pois é o tempo, o clima, a afinação, o temperamento em que a vida bastarda jagunça, a vida sem porquê, a vida mostrando que o mistério das coisas é não ter mistério algum por detrás das coisas (Caieiro) pode aparecer nua e crua, em carne viva. Essa talvez seja a "migração" para o "mundo antimoderno do tempo real", de que fala Miller. Ele fala de "migração" e não de emigração ou imigração — isso me parece importante, pois ele retirou os prefixos da origem e os sufixos das destinações, deixando só o verbo, o movimento. Talvez se possa entender essa migração para o mundo antimoderno do tempo real como uma migração para onde se está, algo como um "cair na real" onde já sempre se está, na vida bastarda e jagunça, só que tomando esse "tropeço" como um novo compasso da vida e do viver. Seria a descoberta do antimoderno do moderno e não da negação do moderno como um novo começo ou uma nova era. Na Carta essa migração é o início da correspondência, o início desse livro a quatro mãos, a duas almas, esse livro de mil páginas, mil passos de caminhada, o Hamlet de Miller a Fraenkel e Fraenkel a Miller. Exagerando esse sentido, talvez se pudesse até dizer que essa migração acaba mostrando que o moderno se opõe ao antigo, ao grego, à natureza como a morte se opõe à vida. Morte se opõe à vida não se opondo a ela. Será essa a loucura de Hamlet? Ou será essa a sua tremenda lucidez, uma lucidez tão transparente e forte que ofusca quem a olha sendo ao mesmo tempo a única luz de onde se pode ver com vivacidade o dar-se da vida e do viver? Será isso que a "morte-na-vida" significa? Se Hamlet é morte-na-vida como morte e vida se opõem? Opõem-se unindo-se, ou seja, fazendo aparecer que vida é morte e morte é vida e isso de tal modo que a identidade de vida e morte é a sua diferença.

Esses termos são talvez demasiado metafísicos mas o que estou tentando exprimir é o sentido de tempo e história que as Cartas descobrem em ou talvez sobretudo a partir de Hamlet. Pois assim o moderno, o pesadelo de uma natureza desnaturada, se opõe ao grego, o sonho de natureza sempre nascente, não como a 
oposição mediante a sucessão de passado, presente e futuro - que afirma que o passado é corpo fechado, irreversível, tempo perdido - mas como descompasso no compasso do tempo, descontinuidade na continuidade do tempo, cesura no ritmo do tempo. A figura - a experiência de um fim que não acaba de acabar, de Hamlet em nossas entranhas, de um tempo desconjuntado, parece indicar uma outra experiência do tempo nesse "pêndulo enferrujado" da alma do nosso tempo. À guisa de ensaio (não há na verdade nenhuma outra guisa possível hoje!) talvez possamos chamar de ritmo o que o pêndulo enferrujado de nossa alma chama tempo (tempo crônico das cronologias). Grego e moderno, natureza nascente, natureza desnaturada, antimoderno, moderno, antinatural, natureza, não seriam portanto oposições mas contrações e dilatações do hífen indissolúvel de vida e morte. Sem dúvida, ritmo tem aqui um sentido diferente de mera continuidade ou repetição. Está mais perto de pulsão, das batidas, sem começo e sem fim de um certo coração na vida do mundo. Talvez seja por isso, que Hamlet aparece como o drama do homem moderno. É do homem que se está falando, não é? Não será Hamlet — esse sem começo e sem fím — essa vida sem por quê que não suporta ser sem porquê e sem fim, essa vida sem fim que não suporta ser sem fim por ser infinitamente finita — o drama do homem se insurgindo contra a vida sem começo e sem fim, em todos os tempos?

Nas Cartas essa migração para o mundo antimoderno do tempo real é descrita como andança e caminhada (walking) de mil páginas. As páginas são os passos dessa migração. As Cartas são essa migração à medida que nas Cartas as palavras têm pensamentos diferindo das palavras por palavras, de pensamentos por pensamentos - esses que nunca alcançam o céu, como ouvimos da boca de Hamlet (do Hamlet de Shakespeare). O acolhimento do horror da monstruosidade humana, que nada tem a ver com condescendência ou fatalismo, o acolhimento do mundo na suas faces diurnas e noturnas, o acolhimento da vida bastarda, sem começo e sem fim, da vida jogada sem porquê, sem eira nem beira, é descrito na Carta como "momento da experiência do tempo real" e esse como o momento "em que decidimos escrever o livro". É o momento da palavra-pensamento, do pensamentopalavra, um momento sempre dramático pois é o momento em que o mundo se 
interrompe e suspende fazendo aparecer um outro mundo dentro do mesmo mundo, um outro tempo dentro do tempo, um outro espaço dentro do espaço, linguagem dentro da linguagem, o pensamento dentro do pensamento. É o momento do drama, ou talvez ainda mais enfaticamente, o drama do momento, pois aí o mundo se interrompe e o fim que não acaba de acabar e o começo que nunca começa coincidem e, assim, a vida bastarda aparece como vida transformada.

Querida Helena, não sei se faz algum sentido tudo isso que escrevi, com coração batendo a mistura de pressa e calma, a pressa de lutar contra o tempo para te enviar essas linhas a tempo e a calma de poder conversar com você, assim, no tempo das cartas, esse tempo que dá tempo aos tempos da fala e da escuta. Senti-me tão inspirada pela sua carta, pela força do seu pensamento em prosa que me deu vontade de seguir escrevendo, de imediatamente começar a traduzir a resposta de Fraenkel, de abandonar tudo o que ainda está por se fazer para habitar esse tempo real, o tempo da nossa conversa de Hamlet para Hamlet!

Um abraço com muitas saudades, 